\title{
SERUM GONADOTROPHIN CONCENTRATIONS IN INFANTILE FEMALE MICE
}

\author{
J. DULLAART,* JOYGE KENT $\dagger$ AND MARGARET RYLE $\dagger$ \\ * Department of Anatomy, Erasmus University, Rotterdam, and \\ $\dagger$ Department of Clinical Endocrinology, Birmingham and Midland \\ Hospital for Women, Showell Green Lane, Sparkhill, Birmingham B11 4HL
}

(Received 10th October 1974)

High concentrations of FSH occur in the serum of rats aged 10 to 20 days accompanied, around Day 15, by elevated, but variable concentrations of $\mathrm{LH}$ (Meijs-Roelofs, Uilenbroek, Osman \& Welschen, 1973; Meijs-Roelofs, Uilenbroek, de Jong \& Welschen, 1973). Rapid follicular growth occurs in the mouse ovary within the 1st week after birth (Pedersen, 1969), suggesting that serum FSH concentrations may be high during the infantile period in this species also. Changes in the relative abundance of follicles of different sizes between Days 16 and 20 of age suggest that LH is subsequently of increasing importance for follicular growth (Kent, 1972). The present work was undertaken to determine what changes in gonadotrophin levels occur during prepubertal development in the mouse.

Mice of the CFW outbred strain were reared in the standard way used for parallel morphological and histochemical studies (Kent, 1972; Kent \& Ryle, 1975). Blood was collected following decapitation immediately after inducing anaesthesia with ether. It was allowed to clot overnight at $4^{\circ} \mathrm{C}$ and the serum was stored at $-20^{\circ} \mathrm{C}$ until assay. The samples assayed consisted of $1-\mathrm{ml}$ pools obtained from a number of animals. Single pools were obtained from mice less than 15 days old since as many as thirty animals were required for each pool. Duplicate pools were obtained from older mice, each normally being taken from a single foster litter of ten females. Serum samples were collected from Day 4 to Day 40 after birth, the day on which each litter was first found being termed Day 0. Code numbers were assigned to the samples before assay. Assays were also carried out on large serum pools from female mice aged 5 to 6 weeks and from adult males 2 or more weeks after castration.

Serum FSH and LH were measured in each sample by radioimmunoassay (RIA). Rat FSH and LH for iodination were kindly provided by the National Institute of Arthritis and Metabolic Diseases, Bethesda, Maryland, U.S.A. Specific antisera raised in rabbits against ovine LH and FSH (NIH-LH-S17 and NIH-FSH-S9, respectively), which showed good cross-reactivity with mouse gonadotrophins, were used. The properties of these ovine antisera in the radioimmunoassay of rat LH and FSH have been investigated in detail (Welschen, Osman, Dullaart, de Greef, Uilenbroek \& de Jong, 1975), but purified hormones were not available for checking the specificity and accuracy of the mouse gonadotrophin assays. A standard mouse pituitary gonadotrophin preparation 
was used, which contained $0.575 \mathrm{NIH}-\mathrm{FSH}-\mathrm{S} 1 \mu \mathrm{g}$ equiv. $/ \mu \mathrm{g}$ and $0.03 \mathrm{NIH}-\mathrm{LH}-$ $\mathrm{S} 1 \mu \mathrm{g}$ equiv. $/ \mu \mathrm{g}$. With these materials, the sensitivities (defined as the amount of standard required to depress binding to $90 \%$ of that occurring in the absence of unlabelled hormone) of the RIA for mouse LH and FSH were estimated as $5.3 \pm 3.7 \mathrm{ng}$ mouse standard in the LH assay and $8.7 \pm 7.4 \mathrm{ng}$ mouse standard in the FSH assay (mean \pm S.D.; $n=5$ and 4 respectively). The inter-assay coefficient of variation was $13.0 \%$ for $\mathrm{LH}$ and $7.3 \%$ for FSH. Assay results are expressed as nanograms of the mouse standard per ml serum.

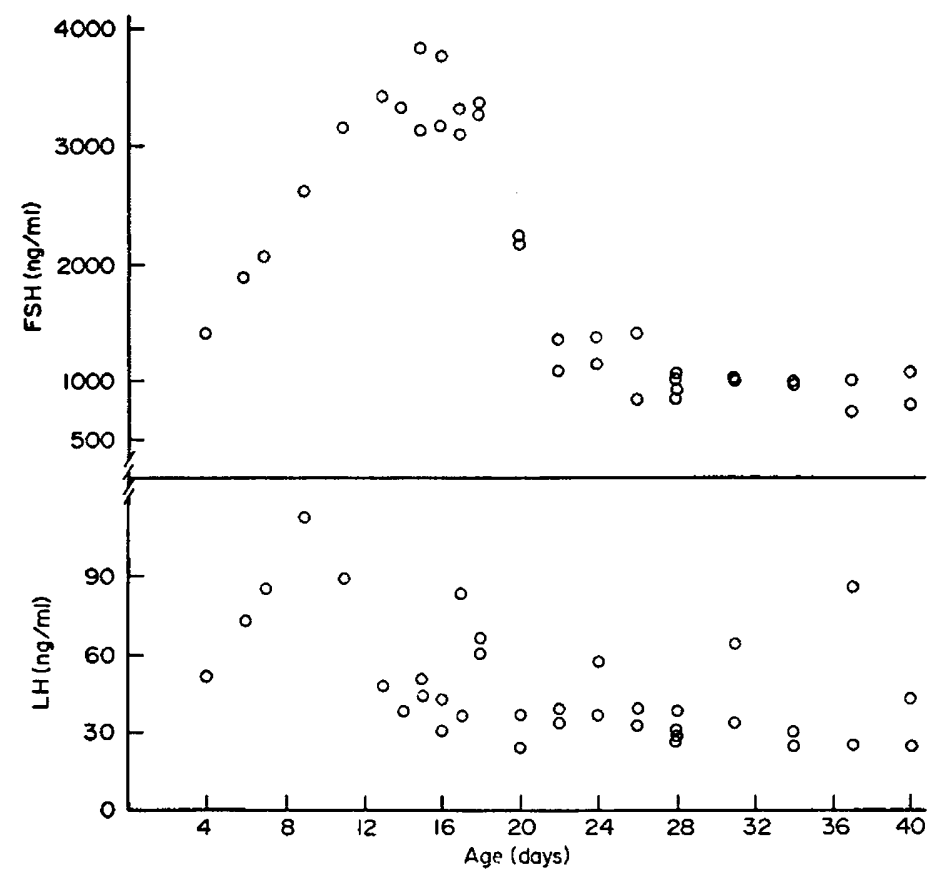

Text-Fig. 1. Serum gonadotrophin concentrations in mice aged 4 to 40 days. Each symbol represents a pool of serum derived from up to thirty ( $<15$ days of age) or ten mice.

The concentration of serum FSH in 4-day-old mice was $1404 \mathrm{ng} / \mathrm{ml}$ (Textfig. 1). It increased steadily until Day 13 , by which time it was within the range found in three pools from adult castrated males (2901, 4149 and $4429 \mathrm{ng} / \mathrm{ml}$ ). After remaining at about this level until Day 18, it declined sharply until Day 22 , and by Day 28 and thereafter was similar to that in the two large pools of serum from female mice aged 5 to 6 weeks $(805$ and $873 \mathrm{ng} / \mathrm{ml}$ ).

The concentration of $\mathrm{LH} 4$ days after birth was $52 \mathrm{ng} / \mathrm{ml}$ and initially it rose steadily. Between Days 9 and 13, however, it fell to the range found in the large serum pools from mice aged 5 to 6 weeks $(19$ and $48 \mathrm{ng} / \mathrm{ml}$ ). From Day 13 to Day 22, the concentration did not exceed $50 \mathrm{ng} / \mathrm{ml}$, except that one of the two duplicate pools on Day 17 and both pools on Day 18 contained 60 or more $\mathrm{ng} / \mathrm{ml}$. On Days 24 and 31, one of each pair of values was elevated but, in general, $\mathrm{LH}$ concentrations remained low from 3 to 5 weeks. 
The serum concentrations of FSH observed in early prepubertal mice were markedly higher than those found in the late prepubertal stage. The concentrations of $\mathrm{LH}$ were also initially often higher than most of those in the later period. Rising gonadotrophin levels between Days 4 and 9 coincided with rising activities of ovarian gonadotrophin-responsive enzymes in similar mice (Kent \& Ryle, 1975). The decline of LH between Days 9 and 13 was immediately preceded by a rapid change in uterine morphology ( $\mathrm{J}$. Kent, unpublished data) suggesting that increasing serum oestrogen may have inhibited LH release. Presumably the level, or type, of steroid required to suppress FSH release is not present at this stage as its serum concentration continued to rise. The brief peak of LH indicated on Days 17 to 18 requires further confirmation. Nevertheless, it was followed by a precipitous decline of serum FSH, suggesting that it initiated a new surge of steroid production which was sufficient to suppress the release of both gonadotrophins.

Stiff, Bronson \& Stetson (1974) measured FSH and LH in infantile mice at 5-day intervals from birth to 25 days. They found a large FSH peak and a small LH peak at 10 days. More frequent sampling might have shown an earlier and larger peak corresponding to that at 9 days reported here. Nevertheless, differences between mouse strains are indicated by the marked decline in FSH concentration which Stiff et al. (1974) found between 10 and 15 days compared to the high levels observed until 18 days in the present work.

Since radioimmunoassays measure the immunological, not the biological activity of gonadotrophins, the high levels found in very young rodents could be due to biologically inactive material. Although histochemical observations indicate that exogenous gonadotrophins induce no additional effect during the 1st week after birth (Kent \& Ryle, 1975), both FSH and LH are essential for normal early post-natal ovarian development (Eshkol, Lunenfeld \& Peters, 1970). This suggests that available binding sites rather than ineffective endogenous hormone initially limits follicular development and that at least part of the LH and FSH detected by radioimmunoassay was biologically effective.

We wish to thank Dr W. G. Beamer, Jackson Laboratory, Bar Harbor, Maine, U.S.A., and the NIAMD for materials used in the assays, Dr W. R. Butt for his encouragement and both the Ford Foundation and The Organization for Medical Research in the Netherlands (FUNGO) for financial support.

\section{REFERENGES}

Eshkol, A., Lunenfeld, B. \& Peters, H. (1970) Ovarian development in infantile mice; dependence on gonadotrophic hormones. In Gonadotrophins and Ovarian Development, pp. 249-258. Eds. W. R. Butt, A. C. Crooke and M. Ryle. Livingstone, Edinburgh.

KENT, J. (1972) Changes in the ovarian follicle population of mice aged 16 to 20 days. J. Reprod. Fert. 31, 323-326,

KeNT, J. \& Ryle, M. (1975) Histochemical studies on three gonadotrophin-responsive enzymes in the infantile mouse ovary. 7. Reprod. Fert. 42, 519-536.

Meijs-Roelofs, H. M. A., Uilenbroek, J. T. J., de Jong, F. H. \& Welschen, R. (1973) Plasma oestradiol-17 $\beta$ and its relation to serum follicle-stimulating hormone in immature female rats. 7. Endocr. 59, 295-304.

Meijs-Roelofs, H. M. A., Uilenbroek, J. T. J., Osman, P. \& Welschen, R. (1973) Serum levels of gonadotrophins and follicular growth in rats. In The Development and Maturation of the Ovary and its Functions, pp. 3-11. Ed. H. Peters. Excerpta Medica Int. Congr. Ser. No. 267. 
Pedersen, T. (1969) Follicle growth in the immature mouse ovary. Acta endocr., Copenh. 62, 117-132. Stiff, M. E., Bronson, F. H. \& Stetson, M. H. (1974) Plasma gonadotropins in prenatal and prepubertal female mice: disorganization of pubertal cycles in the absence of a male. Endocrinology, 94, 492-496.

Welschen, R., Osman, P., Dullaart, J., de Greef, W., Uilenbroek, J. T. J. \& de Jong, F. H. (1975) Levels of follicle stimulating hormone, luteinizing hormone, oestradiol-17 $\beta$ and progesterone and follicular growth in the pseudopregnant rat. F. Endocr. (in press). 